\section{MORFOMETRIA E DNA MITOCONDRIAL DE POPULAÇÕES SUL AMERICANAS DE LUTZOMYIA (NYSSOMYIA) INTERMEDIA (LUTZ \& NEIVA, 1912) (DIPTERA, PSYCHODIDAE, PHLEBOTOMINAE)}

Foi estudada a morfologia de 705 exemplares de Lutzomyia intermedia s. l. (Lutz \& Neiva, 1912) (Diptera, Psychodidae, Phlebotominae) (342 fêmeas e 363 machos), com 39 medidas ou contagens de estruturas anatômicas e várias proporções entre medidas, para cada sexo, realizando-se ANOVA. A comparação das várias estruturas e medidas permitiu distinguir Lutzomyia intermedia s.s. e Lutzomyia neivai (Pinto, 1926), cuja ressurreição é proposta. As fêmeas de Lutzomyia intermedia s. $s$. têm as espermatecas mais longas e com as cabeças mais largas, os dutos individuais mais curtos, em relação ao comprimento das espermatecas, e o duto comum mais longo, em relação aos individuais, que Lutzomyia neivai. Lutzomyia intermedia s. s. tem, em geral, oito dentes horizontais no cibário, enquanto Lutzomyia neivai tem dez ou 12, além de várias outras diferenças em medidas e proporções. Os machos das duas espécies apresentam várias diferenças significativas, mas não podem ser distinguidos com segurança, quando dissociados de fêmeas. Ambos os sexos de Lutzomyia intermedia s. s. e o macho de Lutzomyia neivai são redescritos e a fêmea de Lutzomyia neivai é descrita. Pertencem a Lutzomyia intermedia s. $s$. exemplares de São Paulo, provenientes de localidades ao leste da Serra do Mar, e do Rio de Janeiro, Espírito Santo, Bahia, Pernambuco e Piauí, além de localidades no leste de Minas Gerais. Os flebotomíneos coletados em localidades na Serra do Mar e ao oeste desta, no Estado de São Paulo, e nos estados de Goiás, Paraná, Santa Catarina, Rio Grande do Sul e no oeste de Minas Gerais, além de Paraguai, Argentina e Bolívia, são exemplares de Lutzomyia neivai. Ambas as espécies são simpátricas em Pariqüera Açu, no sul de São Paulo. No limite sul da distribuição conhecida de Lutzomyia intermedia s. s., só foram obtidos exemplares em baixas altitudes, enquanto, nas mesmas latitudes e em maiores, Lutzomyia neivai foi coletado em altitudes bem maiores, indicando

Recebido para publicação em 02/07/97.

\section{MORPHOMETRY AND MITOCHONDRIAL DNA OF LUTZOMYIA (NYSSOMYIA) INTERMEDIA (LUTZ \& NEIVA, 1912) (DIPTERA, PSYCHODIDAE, PHLEBOTOMINAE)}

The morphology of 705 specimens of Lutzomyia intermedias. $l$. (Diptera, Psychodidae, Phlebotominae) (342 females and 363 males) was studied, using 39 measurements or counting of structures for each sex, realizing ANOVA. The observation of several structures and measurements permitted the separation of Lutzomyia intermedias. $s$. and Lutzomyia neivai (Pinto, 1926), whose resurrection is proposed. Lutzomyia intermedias. $s$. spermathecae are longer, their heads are wider, the individual ducts are shorter, compared to spermathecae, and also the common duct is longer, compared to the individual, than in Lutzomyia neivai. Additionally, Lutzomyia intermedia s. $s$. usually has 8 cibarial horizontal teeth and Lutzomyia neivai has 10 or 12. Several significant differences between males of each species were observed but they can not be securely distinguished when not associated with females. Both sexes of Lutzomyia intermedias. s. and the male of Lutzomyia neivai are redescribed and the female of Lutzomyia neivai is described. Specimens from localities in the east of Serra do Mar in São Paulo, in the eastern part of Minas Gerais, and in the states of Pernambuco, Bahia, Espírito Santo and Rio de Janeiro were identified as Lutzomyia intermedias. s. and specimens from the Serra do Mar and to its west, in São Paulo, in the west of Minas Gerais, and in the states of Paraná, Santa Catarina and Rio Grande do Sul and in Paraguay, Argentina and Bolivia as Lutzomyia neivai. Both are sympatric in Pariqüera Açu, in the south of São Paulo. In the southern limit of the known distribution of Lutzomyia intermedia s. s., it was collected only at low altitudes, while Lutzomyia neivai, at the same and in greater latitudes, was collected in much greater altitudes, indicating that Lutzomyia neivai is better adapted to colder regions than Lutzomyia intermedia s. s. Several structures of Lutzomyia intermedia $s$. $s$. specimens collected in higher localities in Espírito Santo State were larger than those of specimens colected near the coast, and several structures of females collected in July were different from those of females collected in December. The proportions of palpal indices were different 
Resumo de Tese. Marcondes CB. Morfometria e DNA mitocondrial de populações sul americanas de Lutzomyia (Nyssomya) intermedia (Lutz \& Neiva), 1912) (Diptera, Psychoidae, Phlebotominae). Revista da Sociedade Brasileira de Medicina Tropical 30:533-534, nov-dez, 1997.

melhor adaptação desta a climas mais frios. Várias medidas de indivíduos de Lutzomyia intermedia s. s. foram maiores em exemplares capturados em maiores altitudes e latitudes e diferentes em insetos fêmeas capturados em junho ou dezembro. Nas duas espécies, as proporções de machos e de fêmeas com cada índice palpal foram significativamente diferentes e se constatou diferenças regionais entre as proporções de cada índice palpal. As medidas e proporções de asas de fêmeas e de machos apresentaram várias diferenças significativas. A análise de sequência de DNA mitocondrial de exemplares provenientes de seis localidades de cinco estados do Brasil permitiu separar dez haplótipos Cada haplótipo estava associado a insetos com morfologia de uma das duas espécies, com exceção de um, que ocorreu em insetos com morfologia das duas espécies, levando a suspeitar de introgressão. Os haplótipos diferiram por apenas 0,2 a 1,1\%, o que indica origem recente da separação. É atualizada a distribuição geográfica e a importância médica de Lutzomyia intermedia s. $l$. in males and females, and there were regional variations in the proportions of each index. The measurements and proportions of female and male wings presented several significant differences. The analysis of mitochondrial DNA sequences of specimens from six localities of Brazil permitted the separation of 10 haplotypes. Each haplotype was associated with insects morphologically identified as one or the other species, except one, inducing the suspicion of introgression. Haplotypes differed by just 0.2 to $1.1 \%$, indicating recent origin of separation. The current geographical distribution and knowledge of medical importance of Lutzomyia intermedia s.l. are shown.

\section{Carlos Brisola Marcondes}

Tese apresentada ao Setor de Ciências Biológicas da Universidade Federal do Paraná, para a obtenção do título de Doutor Curitiba, PR, Brasil, 1997. 